\title{
POTASSIUM ACETATE SOLUTION AS A PROMISING OPTION TO OSMOTIC DISTILLATION FOR SOUR CHERRY (PRUNUS CERASUS L.) JUICE CONCENTRATION
}

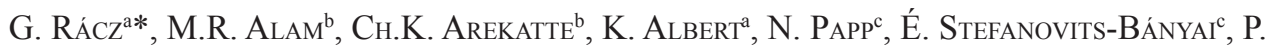 \\ Russo $^{d}$, M. DiMatteo ${ }^{b}$ and Gy. VAtai ${ }^{a}$

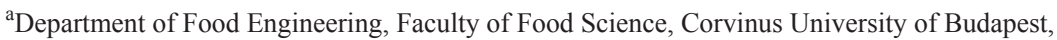 \\ H-1118 Budapest, Ménesi út 44. Hungary \\ ${ }^{\mathrm{b}}$ Department of Industrial Engineering, University of Salerno, Via Ponte don Melillo, 84084, Fisciano, Salerno. \\ Italy \\ ${ }^{c}$ Department of Applied Chemistry, Faculty of Food Science, Corvinus University of Budapest, \\ H-1118 Budapest, Villányi út 29-31. Hungary \\ ${ }^{\mathrm{d}}$ Department of Chemical Engineering Materials Environment, Sapienza University of Rome, Via Eudossiana 18, \\ 00184, Rome. Italy
}

(Received: 9 April 2014; accepted: 12 June 2014)

Different osmotic agents $(\mathrm{OA})$, such as potassium acetate $\left(\mathrm{CH}_{3} \mathrm{COOK}\right)$, potassium carbonate $\left(\mathrm{K}_{2} \mathrm{CO}_{3}\right)$ and ammonium nitrate $\left(\mathrm{NH}_{4} \mathrm{NO}_{3}\right)$, have been examined as alternatives to the traditionally used calcium chloride $\left(\mathrm{CaCl}_{2}\right)$ for osmotic distillation concentrating of clarified and pre-concentrated sour cherry (Prunus cerasus L.) juice. Comparison of the process performances based on the permeate fluxes has been carried out. Regarding the permeate flux results, simplified estimation of the overall mass transfer coefficient of the most effective osmotic agent and the reference $\left(\mathrm{CaCl}_{2}\right)$ solution has been also performed. Furthermore, analytical methods such as total antioxidant activity (TAA) and total polyphenolic content (TPC) using spectrophotometric assays have been also carried out to evaluate the effect of the osmotic distillation on the valuable compounds content of concentrated sour cherry juice. $\mathrm{CH}_{3} \mathrm{COOK}$ was found to be the most effective, resulted more than $25 \%$ higher permeate flux during the sour cherry juice concentration. $\mathrm{K}_{2} \mathrm{CO}_{3}$ and $\mathrm{NH}_{4} \mathrm{NO}_{3}$ were less effective. The simplified mass transfer estimation showed that the $\mathrm{CH}_{3} \mathrm{COOK}$ is more effective only at near saturated concentrations compared to the $\mathrm{CaCl}_{2}$. Regarding the TAA and TPC contents, a significant loss was found in case of all OAs during the concentration procedures.

Keywords: sour cherry juice concentration, Prunus cerasus L, osmotic distillation, potassium acetate, total antioxidant activity, total polyphenolic content

Sour cherry (Prunus cerasus L.) is one of the most appreciated fruits in Hungary due to its attractive aroma, unique taste and richness in phenolic compounds, which are important to the human diet (Lugasi \& HóvÁri, 2002; Bušic et al., 2008; StéGer-Máté et al., 2010; CsERJÉsI et al., 2011). Thus, gentle preservation of its original benefits is essential. Traditional thermal concentration techniques such as evaporation and vacuum evaporation can result in subsequent losses of valuable compounds that possess health benefits in fruit juices (SouzA et al., 2013). Several emerging techniques attempt to find solutions for gentle preservation of fruit without applying high temperature treatment, such as high hydrostatic pressure (DALMADI et al., 2007) or using membranes. Osmotic distillation (OD) is an emerging alternative for concentration of thermo-sensible solutions such as fruit juices. Several fruit juices have been

\footnotetext{
* To whom correspondence should be addressed.

Phone: +36-1-482-6114; e-mail:gabor.racz2@uni-corvinus.hu
} 
already concentrated gently by using osmotic distillation, such as apple juice (BÉLAFI-BAKÓ \& Koroknai, 2006), cornelian cherry (BÉlAFi-BAKó \& Boór, 2011), orange juice (Alves \& Coelhoso, 2006), kiwifruit juice (CAssano \& Drioli, 2007), pineapple juice (Hongvaleerat et al., 2008), noni juice (VALDES et al., 2009), roselle extract (Cissé et al., 2011), camu-camu juice (Rodrigues et al., 2004), and cactus pear juice (CAssano et al., 2007).

In OD the vapour pressure gradient resulted from concentration gradient from the feed to the permeate side of a hydrophobic membrane is generated using an osmotic agent (OA) on the permeate side, frequently $\mathrm{CaCl}_{2}$ brine solution. In this process the hydrophobic nature of a porous membrane prevents flooding the pores by aqueous solutions, thus, air gaps are being created within the membrane. Meanwhile, liquid-vapour interfaces are formed at the entrance of the pores and vapour transfer occurs.

It is well-known that OD technique suffers scale-up difficulties regarding the relatively low process performance and the management of the spent OAs. Up to now only a few studies have paid attention to explore new OAs overcoming these barriers. Selection of an appropriate $\mathrm{OA}$ for use on industrial scale should be in accordance with several requirements. It has to be thermally stable, non-volatile as well as non-corrosive to ferrous alloys. For food industrial applications the OA has to be also non-toxic, food-grade quality, and should also be readily available at low cost. Furthermore OAs should have a high osmotic activity (high water-solubility) in order to maintain the low water vapour pressure above the solution and, thereby, maximize the driving force for water removal. Celere and Gostoli (2004) investigated aqueous solutions of propylene glycol, glycerol, and glycerol-salt mixtures as alternative to $\mathrm{CaCl}_{2}$. They found that among these solutions the $\mathrm{CaCl}_{2}$ showed to be the most effective; however, organic OAs as propylene glycol and glycerol allow obtaining comparable fluxes with advantages related to the absence of corrosion and scaling. They presented that the weak point of glycerol is the high viscosity; nevertheless, the operation is possible also with narrow capillaries. Furthermore, propylene glycol showed a low penetration pressure through the membrane pores, in addition, it diffused towards the juice in considerable amount, owing to the not negligible volatility at room temperature. SHIN and JoHNSON (2007) examined several osmotic agents with many of the properties required for use in osmotic distillation for water flux and corrosiveness toward stainless steel using distilled water as feed. Traditional agents such as $\mathrm{NaCl}$ and $\mathrm{CaCl}_{2}$ as well as several unused agents such as $\mathrm{CH}_{3} \mathrm{COOK}$ and phosphates $\left(\mathrm{K}_{2} \mathrm{HPO}_{4}, \mathrm{~K}_{4} \mathrm{P}_{2} \mathrm{O}_{7}, \mathrm{~K}_{2} \mathrm{HPO}_{4} / \mathrm{KH}_{2} \mathrm{PO}_{4}(48: 1, w / w), \mathrm{K}_{4} \mathrm{P}_{2} \mathrm{O}_{7} / \mathrm{H}_{4} \mathrm{P}_{2} \mathrm{O}_{7}(10: 1, \mathrm{w} / \mathrm{w})\right.$, and $\left.\mathrm{K}_{2} \mathrm{HPO}_{4} / \mathrm{H}_{3} \mathrm{PO}_{4}(12: 1, \mathrm{w} / \mathrm{w})\right)$ were compared based on water fluxes. With the exception of $\mathrm{K}_{2} \mathrm{HPO}_{4}$, the phosphates and $\mathrm{CH}_{3} \mathrm{COOK}$ produced fluxes in the $2.0 \sim 2.3 \mathrm{~kg} \mathrm{~m}^{-2} \mathrm{~h}^{-1}$ range at their near-saturation concentrations at $23 \pm 2{ }^{\circ} \mathrm{C}$. The fluxes produced by $\mathrm{NaCl}, \mathrm{CaCl}_{2}$, and $\mathrm{K}_{2} \mathrm{HPO}_{4}$ were considerably lower under the same conditions. $\mathrm{NaCl}$ and $\mathrm{CaCl}_{2}$ were substantially more corrosive toward stainless steel than the other agents tested. The use of $\mathrm{CH}_{3} \mathrm{COOK}$ on an industrial scale might be appropriate, however, require regular replacement of the volatile hydrolysis product, $\mathrm{CH}_{3} \mathrm{COOH}$, to compensate for loss during thermal reconcentration.

The main weak point of OD is represented by the difficulty to handle spent OAs. Avoiding the energy demanding re-concentration process of the spent brines, spent brines as side-products seem to be competitive option. Since $\mathrm{CH}_{3} \mathrm{COOK}$ and $\mathrm{K}_{2} \mathrm{CO}_{3}$ are frequently used as food additives, preservatives, and acidity regulators, diluted brines as a side-product of OD process might be negotiable. With respect to $\mathrm{NH}_{4} \mathrm{NO}_{3}$ the diluted solution could be realizable as a constituent of liquid fertilizers. The aim of this preliminary study was to explore new opportunities in OD treatment using alternative OAs. Saturated $\mathrm{CH}_{3} \mathrm{COOK}$ 
solution was studied and compared with traditional $\mathrm{CaCl}_{2}$ solution and other, previously not examined salt solutions such as $\mathrm{NH}_{4} \mathrm{NO}_{3}$, and $\mathrm{K}_{2} \mathrm{CO}_{3}$. Clarified and pre-concentrated sour cherry juice was concentrated further from $20^{\circ}$ Brix to $60^{\circ}$ Brix using all the examined OAs and the performance of these processes was calculated and compared. Simplified estimations of the overall mass transfer coefficient of the most effective OD solution and the classical $\mathrm{CaCl}_{2}$ solution were also performed. Finally, total antioxidant activity (TAA) and total polyphenolic content (TPC) of the sour cherry juice were determined before and after the treatments, and losses of TAA and TPC during the OD processes were calculated.

\section{Materials and methods}

\subsection{Sour cherry juice pretreatments}

Mixture of five Hungarian cultivars of sour cherries ('Érdi bőtermő', 'Debreceni bőtermő', 'Oblacsinszka', 'Pipacs I', 'Újfehértói fürtös') was used as feed for the experiments. After pressing, the initial total soluble solid (TSS) of juice was $9.2^{\circ}$ Brix. Sour cherry juice was clarified using cross-flow microfiltration. Tubular ceramic membrane was applied with $0.45 \mu \mathrm{m}$ pore size (Millipore, Billerica, MA, USA) at $25^{\circ} \mathrm{C}$ and 1.5 bar transmembrane pressure difference. Furthermore, reverse osmosis was applied to pre-concentrate the clarified juice using a spiral wound membrane module (MFT Köln, CD1TYP3, Köln, Germany) with $98 \%$ of $\mathrm{NaCl}$ retention at $30{ }^{\circ} \mathrm{C}$ and 30 bar transmembrane pressure difference. $20^{\circ} \mathrm{Brix}$ of TSS was reached.

\subsection{Osmotic distillation experiments}

Saturated inorganic salt solutions were prepared using deionised water and crystal form of the salts (VWR International Ltd, Debrecen, Hungary) at $30^{\circ} \mathrm{C}$. Table 1 shows the saturation solubility of the four examined salts at $30^{\circ} \mathrm{C}$.

Table 1. Saturation solubility of osmotic agents at $30{ }^{\circ} \mathrm{C}$

\begin{tabular}{lc}
\hline Osmotic agent & $\begin{array}{c}\text { Saturation concentration } \\
(\mathrm{g} / 100 \mathrm{~g} \text { water })\end{array}$ \\
\hline $\mathrm{CH}_{3} \mathrm{COOK}$ & 283.8 \\
$\mathrm{NH}_{4} \mathrm{NO}_{3}$ & 241.8 \\
$\mathrm{~K}_{2} \mathrm{CO}_{3}$ & 113.7 \\
$\mathrm{CaCl}_{2}$ & 102 \\
\hline
\end{tabular}

Source:PERRY (1968)

Figure 1 illustrates the laboratory-scale osmotic distillation equipment. MD $020 \mathrm{CP} 2 \mathrm{~N}$ (Microdyn-Nadir GmbH, Wiesbaden, Germany) hollow fibre polypropylene porous membrane with $0.2 \mu \mathrm{m}$ pore size was applied. The useful membrane area was $0.2 \mathrm{~m}^{2}$. 


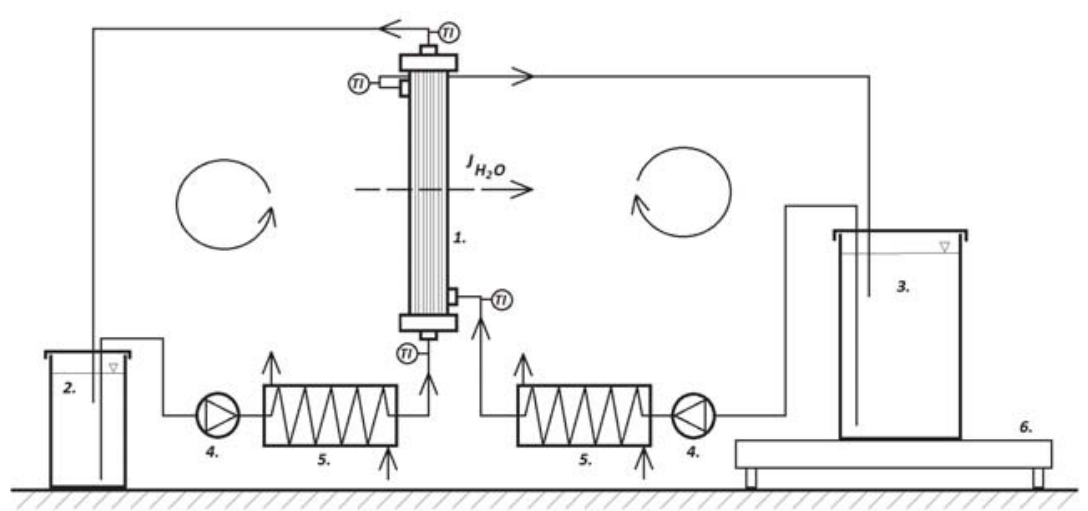

Fig. 1. Laboratory-scale osmotic distillation equipment, 1: membrane module; 2: feed container; 3: OA container; 4: peristaltic pump; 5: heat exchanger; 6: digital balance connected to a PC

Feed (sour cherry juice) was circulated in the capillaries and the OA streams were circulated in the shell side of the module in co-current flow mode with $201 \mathrm{~h}^{-1}$ recirculating flow rate on both flowing channels (laminar flow conditions) and $30{ }^{\circ} \mathrm{C}$ in batch mode. In every separate experiment the initial amount of sour cherry juice was $800 \mathrm{~g}$ with $20^{\circ} \mathrm{Brix}$, and the initial mass of saturated OA was $2000 \mathrm{~g}$. At least $60^{\circ}$ Brix of final concentration of sour cherry juice was tried to be achieved.

\subsection{Evaluation of the permeate flux and the overall mass transfer coefficient}

The calculation of process performance was based on measuring the total mass of osmotic agent during process. The extracted water diffused through the membrane and condensed into the $\mathrm{OA}$, thus, increased the mass of the OA, while the concentration of the OA decreased. It was recorded by a digital balance (Sartorius PMA 7500, Göttingen, Germany) connected to a PC. Equation 1 defines the calculation of process performance as permeate flux:

$$
\mathrm{J}=\frac{1 \Delta \mathrm{m}}{\mathrm{A} \Delta \mathrm{t}}
$$

Equation 2 describes the permeate flux during OD process based on the mass transport phenomenon. $\mathrm{K}$ is the overall mass transfer coefficient, which depends on the flow conditions (laminar, turbulent), the physical properties of the sour cherry juice, and the OA (density, viscosity and diffusivity) as well as the membrane properties (pore size, porosity, tortuosity and membrane thickness).

$$
\mathrm{J}=\mathrm{K} \Delta \mathrm{P}_{\mathrm{b}}
$$

If water activity of the feed and osmotic solution streams can be determined, a simple function can be used to calculate vapour pressure above a certain composition of feed or osmotic agent stream using the equilibrium vapour pressure of the pure water at $30{ }^{\circ} \mathrm{C}$ 
$\left(\mathrm{P}_{\mathrm{w}}^{0}=4243 \mathrm{~Pa}\right)$. It is illustrated in Eq. 3. Based on the previous equations (Eq. 1-3), K can be estimated using Eq. 4:

$$
\begin{aligned}
& \mathrm{P}_{\mathrm{b}}=\mathrm{a}_{\mathrm{w}, \mathrm{b}} \mathrm{P}_{\mathrm{w}}^{0} \\
& \mathrm{~K}=\frac{\mathrm{J}}{\mathrm{P}_{\mathrm{w}}^{0} \Delta \mathrm{a}_{\mathrm{w}, \mathrm{b}}}
\end{aligned}
$$

Water activity values of the sour cherry juice and osmotic agents were determined using

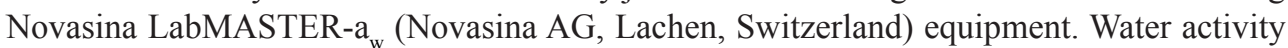
values were determined at different concentrations up to the final concentration of sour cherry juice and the saturation concentration of the examined OAs.

\subsection{Analytical measurement of sour cherry juice concentration}

For determining TAA, spectrophotometric FRAP assay (Ferric Reducing Ability of Plasma) is applied (BENZIE \& StRAIN, 1996). The antioxidant power was calculated from a standard curve obtained by different concentrations of ascorbic acid (mM AAE $\left.1^{-1}\right)$. TPC were determined using Folin-Ciocalteu reagent according to the spectrophotometric method of Singleton and Rossi (1965). The content of soluble phenols was calculated from a standard curve obtained by different concentrations of gallic acid $\left(\mathrm{mM} \mathrm{GAE}^{-1}\right)$.

\section{Results and discussion}

\subsection{Results of the osmotic distillation experiments}

Figure 2 illustrates the permeate fluxes as function of the sour cherry juice concentration using different OAs. It is well observed that the use of $\mathrm{CH}_{3} \mathrm{COOK}$ resulted the highest permeate flux among the examined $\mathrm{OAs}$, and $\mathrm{K}_{2} \mathrm{CO}_{3}$ as well as $\mathrm{NH}_{4} \mathrm{NO}_{3}$ showed a significantly lower permeate flux through the membrane compared to the reference $\mathrm{OA}\left(\mathrm{CaCl}_{2}\right)$. Table 2 summarizes the integrated permeate fluxes as a representative flux value of each concentration treatment. $\mathrm{CH}_{3} \mathrm{COOK}$ possesses $25.2 \%$ higher permeate flux to the reference $\mathrm{CaCl}_{2}$ solution.

Table 2. Average permeate fluxes and the deviance of the fluxes related to $\mathrm{CaCl}_{2}$ operation

\begin{tabular}{lcccc}
\hline & $\mathrm{CaCl}_{2}$ & $\mathrm{CH}_{3} \mathrm{COOK}$ & $\mathrm{K}_{2} \mathrm{CO}_{3}$ & $\mathrm{NH}_{4} \mathrm{NO}_{3}$ \\
\hline $\begin{array}{l}\text { Average permeate flux, } \mathrm{kg} \mathrm{m}^{-2} \mathrm{~h}^{-1} \\
\text { Final TSS sour cherry juice, }{ }^{\circ} \mathrm{Brix}\end{array}$ & 1.4 & 1.8 & 0.4 & 0.9 \\
$\begin{array}{l}\text { Deviance of the permeate flux related to } \\
\text { reference } \mathrm{OA}\left(\mathrm{CaCl}_{2}\right), \%\end{array}$ & -61.8 & 62.2 & 51.2 & 60.4 \\
\hline
\end{tabular}




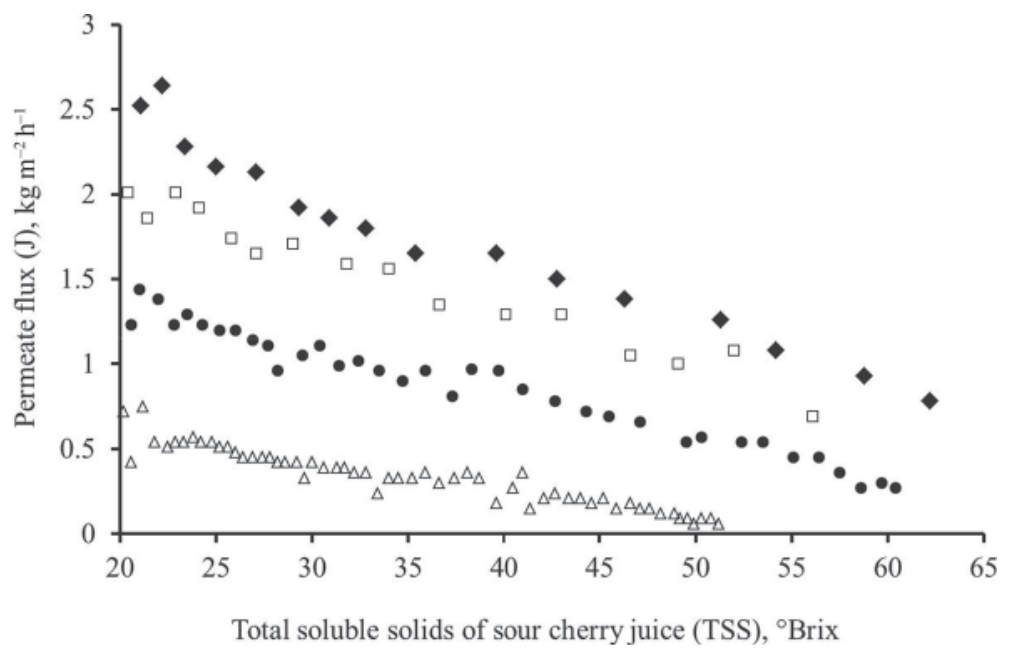

Fig. 2. Permeate flux during the concentration of sour cherry juice using different kind of osmotic agents $\left(\square: \mathrm{CaCl}_{2} ; \bullet: \mathrm{CH}_{3} \mathrm{COOK} ; \Delta: \mathrm{K}_{2} \mathrm{CO}_{3} ; \bullet: \mathrm{NH}_{4} \mathrm{NO}_{3}\right)$

It can be well observed on Figure 3 that it is due to the lower vapour pressure above the $\mathrm{CH}_{3} \mathrm{COOK}$ compared to the reference solution $\left(\mathrm{CaCl}_{2}\right)$, which resulted higher driving force (Fig. 4).

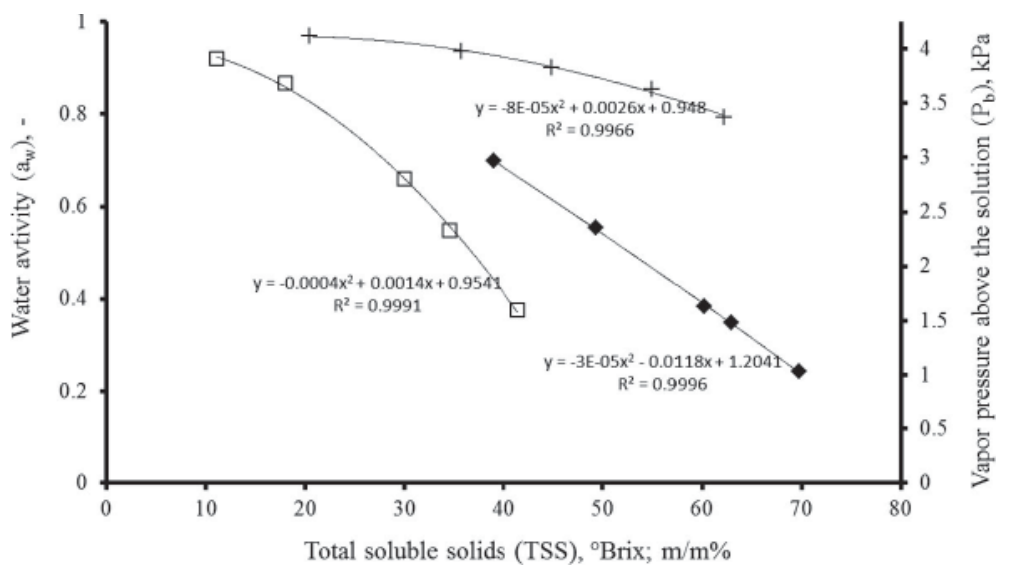

Fig. 3. Water activity of sour cherry juice, $\mathrm{CaCl}_{2}$, and $\mathrm{CH}_{3} \mathrm{COOK}$ as function of total soluble solids $\left(\mathrm{T}=30{ }^{\circ} \mathrm{C}, \mathrm{P}_{\mathrm{w}}{ }^{0}=4243 \mathrm{~Pa}\right)\left(\square: \mathrm{CaCl}_{2} ;: \mathrm{CH}_{3} \mathrm{COOK} ;+\right.$ :sour cherry $)$ 


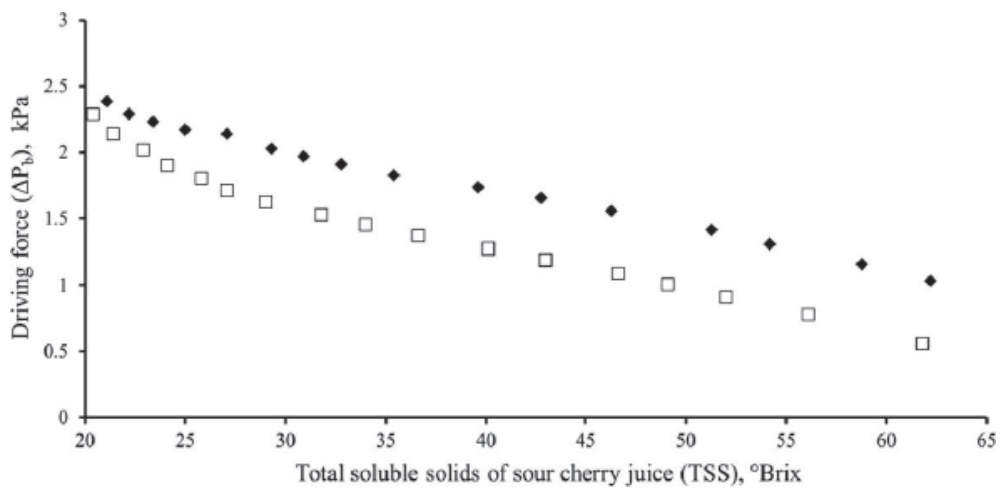

Fig. 4. Driving force of OD processes as function of total soluble solids of sour cherry juice $\left(\square: \mathrm{CaCl}_{2} ;: \mathrm{CH}_{3} \mathrm{COOK}\right)$

The permeate flux value of $\mathrm{CH}_{3} \mathrm{COOK}$ treatment is well-agreed (at $1.2 \mathrm{kPa}$ resulted $2.7 \mathrm{~kg} \mathrm{~m}^{-2} \mathrm{~h}^{-1}, 30{ }^{\circ} \mathrm{C}$ ) (Fig. 5) with Shin and Johnson's (2007) study (at $1.2 \mathrm{kPa}$ resulted $2.3 \mathrm{~kg} \mathrm{~m}^{-2} \mathrm{~h}^{-1}, 23{ }^{\circ} \mathrm{C}$ ). The slight difference is due to the exponential dependence of the permeate flux values on the temperature (Antoine equation).

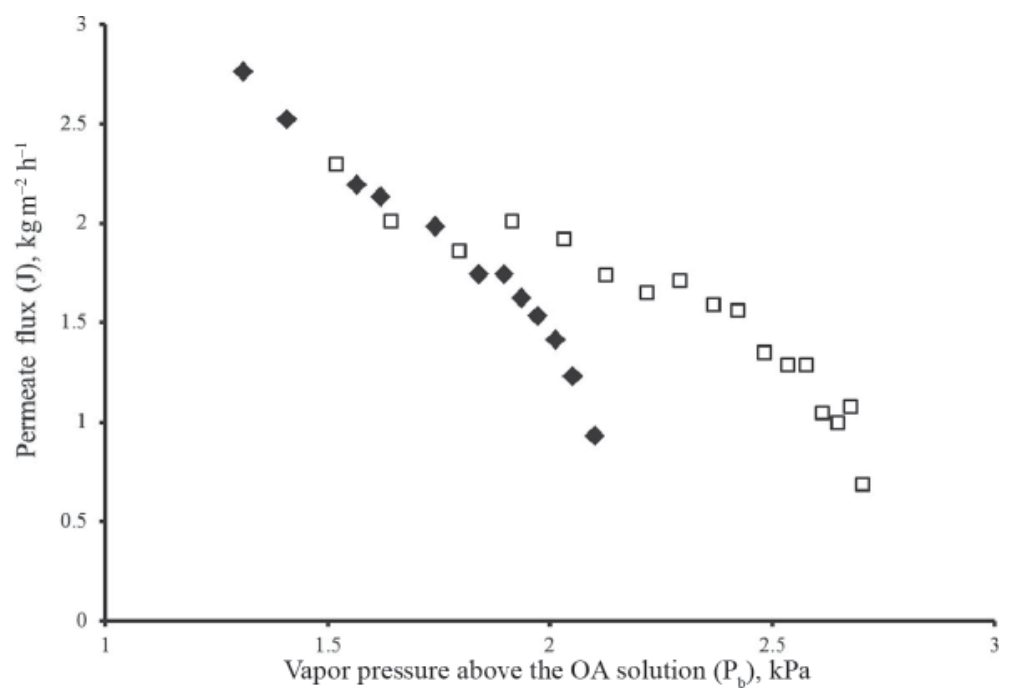

Fig. 5. Permeate flux of OD process as a function of the vapour pressure above the OA solutions $\left(\square: \mathrm{CaCl}_{2} ; \mathrm{CH}_{3} \mathrm{COOK}\right)$

It has to be remarked on Fig. 2 that the permeate flux values difference between $\mathrm{CH}_{3} \mathrm{COOK}$ and $\mathrm{CaCl}_{2}$ is less pronounced in the last part of the process. Here the OAs were already diluted and the driving force decreased significantly. Accordingly, Figure 6 showed that at the same driving force at the end of the process $\mathrm{CaCl}_{2}$ generated higher permeate flux 
compared to the $\mathrm{CH}_{3} \mathrm{COOK}$. It can be explained by the overall mass transfer coefficient (Fig. 7), which was almost constant in case of $\mathrm{CaCl}_{2}$, however, decreased in case of $\mathrm{CH}_{3} \mathrm{COOK}$. This phenomenon can be explained by the differences of the physical-chemical properties of the OAs, such as diffusivity and viscosity.

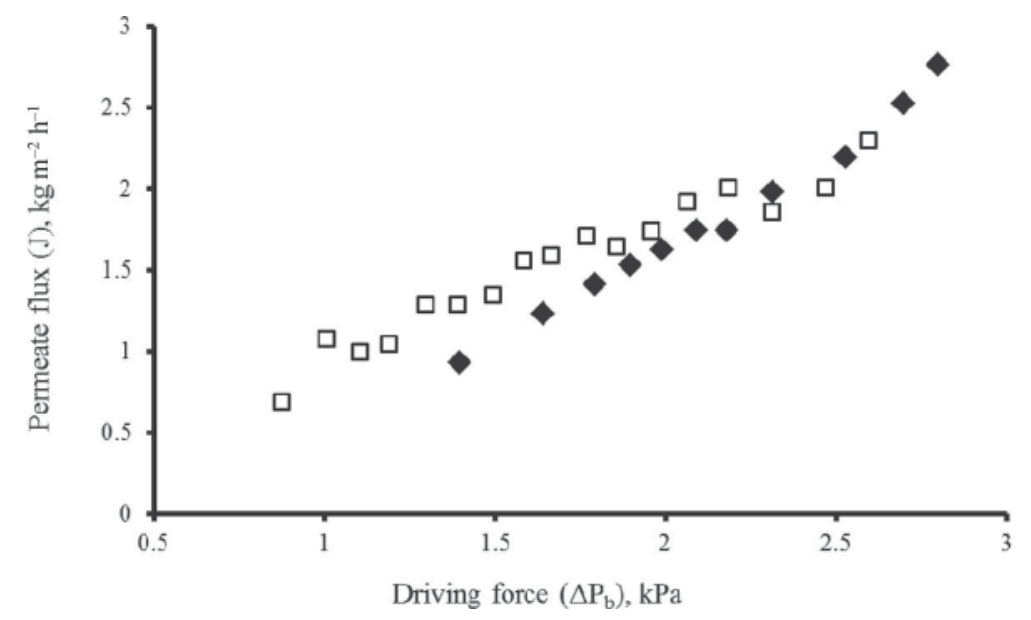

Fig. 6. Permeate flux of the OD processes as function of the driving force ( $\square$ : $\mathrm{CaCl}_{2} ; \mathrm{CH}_{3} \mathrm{COOK}$ )

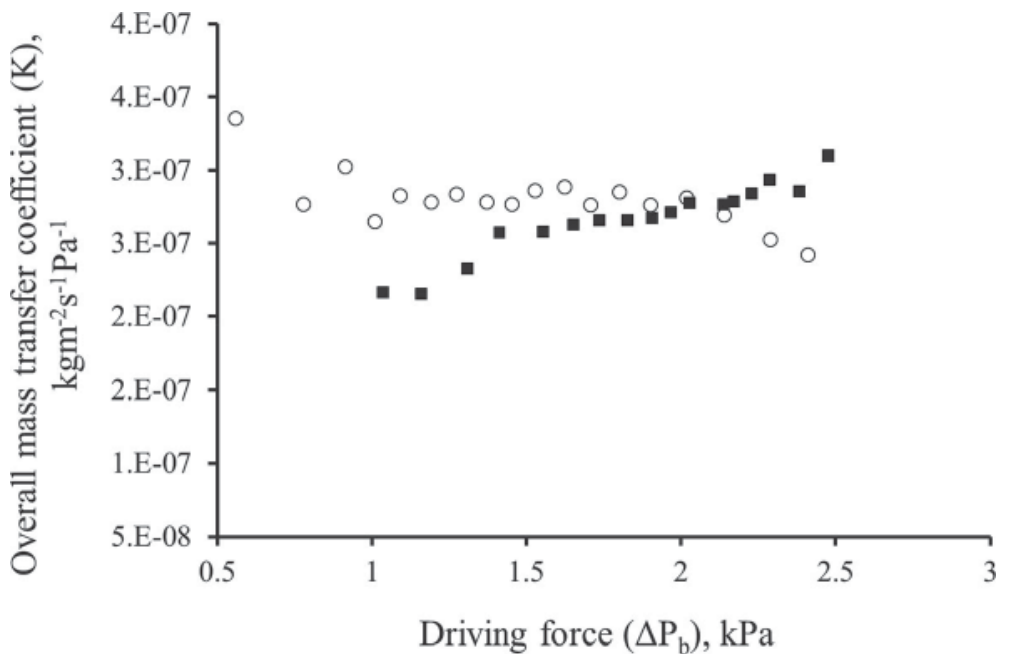

Fig. 7. Overall mass transfer coefficient as function of the driving force (O: $\left.\mathrm{CaCl}_{2} ; \mathbf{m}: \mathrm{CH}_{3} \mathrm{COOK}\right)$

\subsection{Results of the analytical measurement of sour cherry juice concentration}

Table 3 shows the changes of total antioxidant activity (TAA) and total polyphenolic content (TPC) during the sour cherry juice concentration using osmotic distillation treatment applying 
different OAs. Robust Games-Howell statistical analysis was performed. With significant level of $\alpha=0.05$, significant decreasing was found in the AA and TPC content in case of all OD treatments.

Table 3. Effect of osmotic distillation treatment on total antioxidant activity (TAA) and total polyphenolic content (TPC)

\begin{tabular}{lccc}
\hline Treatment & Op. time $(\mathrm{min})$ & $\mathrm{TAA}\left(\mathrm{mMol} \mathrm{AAE} 1^{-1}\right)$ & $\mathrm{TPC}\left(\mathrm{mMol} \mathrm{GAE}^{-1}\right)$ \\
\hline Initial juice & 0 & $5.31 \pm 0.19$ & $6.41 \pm 0.25$ \\
$\mathrm{CH}_{3} \mathrm{COOK}$ & 107 & $4.39 \pm 0.12$ & $4.56 \pm 0.18$ \\
$\mathrm{CaCl}_{2}$ & 120 & $4.36 \pm 0.12$ & $5.08 \pm 0.29$ \\
$\mathrm{NH}_{4} \mathrm{NO}_{3}$ & 180 & $3.60 \pm 0.11$ & $4.25 \pm 0.18$ \\
$\mathrm{~K}_{2} \mathrm{CO}_{3}$ & 474 & $2.85 \pm 0.12$ & $3.50 \pm 0.16$ \\
\hline
\end{tabular}

In respect of the TAA and TPC examinations, a significant loss was found in case of all the OAs during the concentration procedures. It can be an effect of the temperature, but as the laboratory experimental system was not covered totally from the light, it should be the reason for causing such a loss.

\section{Conclusions}

Gentle concentration procedure of sour cherry juice is a challenging task in the food industry. In our study osmotic distillation as a promising technique was applied to pre-concentrated sour cherry juice made from mixture of different sorts of cherries. Different osmotic solutions $\left(\mathrm{K}_{2} \mathrm{CO}_{3}, \mathrm{NH}_{4} \mathrm{NO}_{3}\right.$, and $\left.\mathrm{CH}_{3} \mathrm{COOK}\right)$ were examined as alternatives to the traditionally used $\mathrm{CaCl}_{2}$ osmotic solution. $\mathrm{CH}_{3} \mathrm{COOK}$ was found to be the most effective OA compared to the reference solution $\left(\mathrm{CaCl}_{2}\right)(+25 \%)$ based on the flux measurements, but only if the process can be operated in near saturated OA range. Based on the estimation of overall mass transfer coefficient, it can be stated that at lower OA concentration the $\mathrm{CH}_{3} \mathrm{COOK}$ loses its efficiency and $\mathrm{CaCl}_{2}$ becomes more effective. Analytical measurements of TAA and TPC evinced significant losses of AA and TPC of the treatment. It can be an effect of the temperature, but also light could cause loss because the system was not covered totally from the light.

$\begin{array}{lll}\text { Nomenclature } & \\ \mathrm{J} & \text { Permeate flux } & \left(\mathrm{kg} \mathrm{m}^{-2} \mathrm{~h}^{-1}\right) \\ \mathrm{A} & \text { Useful membrane area } & \left(\mathrm{m}^{2}\right) \\ \mathrm{m} & \text { Total mass of osmotic agent } & (\mathrm{kg}) \\ \Delta \mathrm{t} & \text { Operation time } & (\mathrm{s}) \\ \mathrm{K} & \text { Overall mass transfer coefficient } & \left(\mathrm{kg} \mathrm{m}^{-2} \mathrm{~h}^{-1} \mathrm{~Pa}^{-1}\right) \\ \mathrm{P}_{\mathrm{b}} & \text { Bulk phase vapour pressure } & (\mathrm{Pa}) \\ \mathrm{a}_{\mathrm{wb}} & \text { Water activity of bulk phase } & (-) \\ \mathrm{P}_{\mathrm{w}}^{0} & \text { Pure water vapour pressure } & (\mathrm{Pa})\end{array}$


The authors would like to express their acknowledgement to the Hungarian National Scientific Foundation TÉT 10-1-2011-0072, TÁMOP-4.2.1/B-09/1/KMR-2010-0005 and for project OTKA CK 81011 and OTKA K68596 for the support.

\section{References}

Alves, V.D. \& Coelhoso, I.M. (2006): Orange juice concentration by osmotic evaporation and membrane distillation: A comparative study. J. Food Eng., 74 (1), 125-133.

BÉlAFI-BAKó, K. \& Boór, A. (2011): Concentration of Cornelian cherry fruit juice by membrane osmotic distillation. Desalin. Water Treat., 35, 271-274.

BÉlafi-BaKó, K. \& Koroknai, B. (2006): Enhanced flux in fruit juice concentration: coupled operation of osmotic evaporation and membrane distillation. J. Membr. Sci., 269, 187-193.

Benzie, I.F.F. \& Strain, J.J. (1996): The Ferric Reducing Ability of Plasma (FRAP) as a measure of "antioxidant power": The FRAP Assay. Anal. Biochem., 239, 70-76.

Bušić, V., Kovač, S., Gašo-Sokač, D. \& Lepeduš, H. (2008): Antioxidative activity of anthocyanins from sour cherries, Acta Alimentaria, 37, 391-397.

Cassano, A. \& Drioli, E. (2007): Concentration of clarified kiwifruit juice by osmotic distillation J. Food Eng., 79, 1397-1404.

Cassano, A., Conidi, C., Timpone, R., D’Avella, M. \& Drioli, E. (2007): A membrane-based process for the clarification and the concentration of the cactus pear juice. J. Food Eng., 80, 914-921.

Celere, M. \& Gostoli, C. (2004): Osmotic distillation with propylene glycol, glycerol and glycerol-salt mixtures. J. Membr. Sci., 229, 159-170.

Cissé, M., Vaillant, F., Bouquet, S., Pallet, D., Lutin, F., Reynes, M. \& Dornier, M. (2011): A thermal concentration by osmotic evaporation of roselle extract, apple and grape juices and impact on quality. Innov. Food Sci. Emerg., 12 (3), 352-360.

Cserjési, P, Bélafi-Bakó, K., CsanÁdi, Zs., Beszédes, S. \& Hodúr, C. (2011): Simultaneous recovery of pectin and colorants from solid agro-wastes formed in processing of colorful berries. Progr. Agric. Eng. Sci., 7, 65-80.

Dalmadi, I., Kántor, D.B., Wolz, K., Polyák-Fehér, K., PÁsztor-Huszár, K., Farkas, J. \& Fenete, A. (2007): Instrumental analysis of strawberry puree processed by high hydrostatic pressure or thermal treatment. Progr. Agric. Eng. Sci., 3, 47-66.

Hongvaleerat, C., Cabral, L.M.C., Dornier, M., Reynes, M. \& Ningsanond, S. (2008): Concentration of pineapple juice by osmotic evaporation. J. Food Eng., 88, 548-552.

LugAsi A. \& HóvÁRI J. (2002): Flavonoid aglycons in foods of plant origin II. Fresh and dried fruits. Acta Alimentaria, 31, 63-71.

Perry, J.H. (1968): Vegyészmérnökök kézikönyve (Chemical Engineers Handbook). Müszaki Könyvkiadó, Budapest, pp. 290-293.

Rodrigues, R.B., Menezes, H.C., Cabral, L.M.C., Dornier, M., Rios, G.M. \& Reynes, M. (2004): Evaluation of reverse osmosis and osmotic evaporation to concentrate camu-camu juice (Myrciaria dubia). J. Food Eng., 63 (1), 97-102.

Shin, C.H. \& Johnson, R. (2007): Identification of an appropriate osmotic agent for use in osmotic distillation. J. Ind. Eng. Chem., 13, 926-931.

Singleton, V.L. \& Rossi, J.A. (1965): Colorimetry of total phenolics with phosphomolybdic-phosphotungstic acid reagents. Am. J. Enol. Vitic., 16 (3), 144-158.

Souza, A.L.R., Pagani, M.M., Dornier, M., Gomes, F.S., Tonon, R.V. \& Cabral, L.M.C. (2013): Concentration of camu-camu juice by the coupling of reverse osmosis and osmotic evaporation processes. J. Food Eng., 119 (1), 7-12.

Stéger-Máté, M., Ficzek, G., Kállay, E., Bujdosó, G., Barta, J. \& Tóth, M. (2010): Optimising harvest time of sour cherry cultivars on the basis of quality parameters, Acta Alimentaria, 39, 59-68.

Valdes, H., Romero, J., Saavedra, A., Plaza, A. \& Bubnovich, V. (2009): Concentration of noni juice by means of osmotic distillation. J. Membr. Sci., 330 (1-2), 205-213. 